\title{
Endoscopic Sural Nerve Removal in Obstetric Brachial Plexopathy Using Basic Endoscopy Instruments: Technical Note
}

\section{Retirada endoscópica do nervo sural na plexopatia braquial obstétrica utilizando instrumentos básicos de endoscopia: nota técnica}

\author{
José Augusto Malheiros ${ }^{1,2}$ Sérgio Augusto Vieira Cançado ${ }^{1}$ João Tiago Alves Belo ${ }^{1}$ \\ Luiz Alberto Otoni Garcia ${ }^{1}$ Marcelo Magaldi de Oliveira ${ }^{2}$ Martjin J. A. Malessy ${ }^{3}$
}

${ }^{1}$ Neurological and Neurosurgery Clinic, Hospital Felício Rocho -

Fundação Felice Rosso, Belo Horizonte, MG, Brazil

2 Neurosurgery Department, Hospital das Clínicas, Universidade

Federal de Minas Gerais (HC-UFMG), Belo Horizonte, MG, Brazil

3 Department of Neurosurgery, Leids Universitair Medisch Centrum,

Leiden, Netherlands

\author{
Address for correspondence José Augusto Malheiros, MD, PhD, \\ Departamento de Neurocirurgia do Hospital das Clínicas da \\ Universidade Federal de Minas Gerais (HC-UFMG), Av. do Contorno, \\ 9530. 20 andar., Belo Horizonte, MG, CEP 30110-934, Brasil \\ (e-mail: joseaugustomalheiros@gmail.com).
}

\begin{abstract}
Keywords

- sural nerve

- endoscopy

- brachial plexus

Introduction The sural nerve (SN) is commonly used for grafting following resection of a neuroma-in-continuity in neonatal brachial plexus lesions (NBPL). The main drawbacks of the current open techniques are large scars and contractures in the late postoperative stage, which may, in severe cases, cause equinovarus contractures.

Objective To describe the feasibility and the technical aspects of endoscopic SN harvesting with the use of basic endoscopy instruments and small incisions.

Methods Prospective observational study of NBPL subjected to endoscopic nerve harvesting between February of 2012 and February of 2014 in a consecutive series. Patients were operated at the Felício Rocho Hospital (Hospital Felício Rocho) and the Clinical Hospital, Federal University of Minas Gerais (Hospital das Clínicas UFMG), Belo Horizonte/MG, in Brazil. The study outcomes assessed were: scar size, presence or absence of contractures in the calf, bleeding volume (measured by the number of gauzes used) and number of incisions. Only patients with a follow-up longer than 6 months were included.

Results Seven patients were selected and twelve endoscopic nerves were endoscopically harvested. The average surgery time was 45 minutes. Nine SNs were harvested through two incisions, and three nerves through three incisions. The estimated bleeding was less than $5 \mathrm{ml}$ and there were no complications or contractures during the follow-up period of 6 months to 4 years.
\end{abstract}

received

February 28, 2017

accepted

May 2, 2017
DOI https://doi.org/ 10.1055/s-0037-1603966. ISSN 0103-5355.
Copyright $\odot 2017$ by Thieme Revinter Publicações Ltda, Rio de Janeiro, Brazil 


\section{Resumo}

\section{Palavras-chave}

- nervo sural

- endoscopia

- plexo braquial
Conclusion Sural nerve harvesting in children with NBPL is feasible and it offers the advantage of needing only two or three small incisions using basic endoscopy instruments.

Introdução O nervo sural é a melhor opção para enxertia nas reconstruções microcirúrgicas da plexopatia braquial obstétrica. O método clássico aberto com incisão longitudinal desde o tornozelo até a fossa poplítea ou em incisões em degraus possuem as desvantagens de cicatrizes amplas e contraturas em equinovarus (pé torto). Atualmente, o emprego de endoscópios específicos para a retirada de enxertia de nervos e vasos mostra resultados satisfatórios em relação ao encurtamento do tempo cirúrgico e à redução no tamanho das incisões, mas tem como inconveniente o alto custo de aquisição e manutenção.

Objetivo Discutir a viabilidade e descrever nota técnica da retirada do nervo sural utilizando instrumental básico de endoscopia e pequenas incisões.

Métodos Estudo observacional prospectivo em pacientes com plexopatia braquial obstétrica submetidos a retirada do nervo sural por endoscopia no período de fevereiro de 2012 a fevereiro de 2014 no Hospital Felicio Rocho e no Hospital das Clinicas UFMG, Belo Horizonte/MG, Brasil.

Resultados Sete pacientes foram selecionados e foram retirados doze nervos surais por endoscopia. O tempo médio da cirurgia foi de 45 minutos. Nove nervos surais foram retirados por duas incisões, e três nervos foram retirados por três incisões. $\mathrm{O}$ sangramento foi inferior a $5 \mathrm{ml}$ e não houve complicações no pós-operatório imediato e tardio em acompanhamento entre 6 meses e 4 anos. Não foram observadas contraturas no período observacional.

Conclusão O nervo sural pode ser retirado utilizando duas ou três pequenas incisões por meio de instrumental endoscópico básico em crianças com plexopatia braquial obstétrica.

\section{Introduction}

The sural nerve (SN) is commonly used for grafting following resection of a neuroma-in-continuity in neonatal brachial plexus lesions (NBPL). ${ }^{1,2}$ Generally, the entire length of the $\mathrm{SN}$ is used, which involves large incisions or incisions in multiple steps between the ankle and the popliteal fossa. ${ }^{3-5}$

The main drawbacks of the current open techniques are large scars and contractures in the late postoperative stage, which may, in severe cases, cause equinovarus contractures. 5,6 Other disadvantages related to this technique are the higher intraoperative blood loss, lack of temperature control and postoperative pain and wound infections.

Here we describe the feasibility and technical aspects of SN harvesting with the use of basic endoscopy instruments and small incisions.

\section{Methods}

This was a prospective observational study of patients with NBPL subjected to endoscopic nerve harvesting between February of 2012 and February of 2014 in a consecutive series. The patients were operated at two institutions in the state of Minas Gerais, Brazil. The study outcomes assessed were: scar size, presence or absence of contractures in the calf, bleeding volume (measured by the number of gauzes used) and number of incisions. Only patients with a followup longer than 6 months were included.

\section{Instruments Used}

- Pediatric cystoscope (Karl Storz, Tuttlingen, Germany), thirty-degree lens, $2.7 \mathrm{~mm}$ in diameter and $17.5 \mathrm{~cm}$ in length.

- Nasal speculum numbers $2(5 \mathrm{~cm})$ and $3(7 \mathrm{~cm})$.

\section{Technique of Endoscopic Sural Nerve Harvesting}

1) Placement of an arch on the operating table to position the lower limbs for endoscopy and fixation of the lower limbs onto the arch with sterile tape (-Fig. 1).

2) Ankle incision and SN repair with silicone tape (-Fig. 2A).

3) Preparation of endoscopy instruments: rigid thirty-degree endoscope and two nasal specula (short and long) (-Fig. 2B).

4) Dissection of a tunnel to introduce the nasal speculum that will be the endoscopic working channel (-Fig. 2C).

5 ) Introduction of the endoscope and dissection of the sural nerve (-Fig. 2D). 


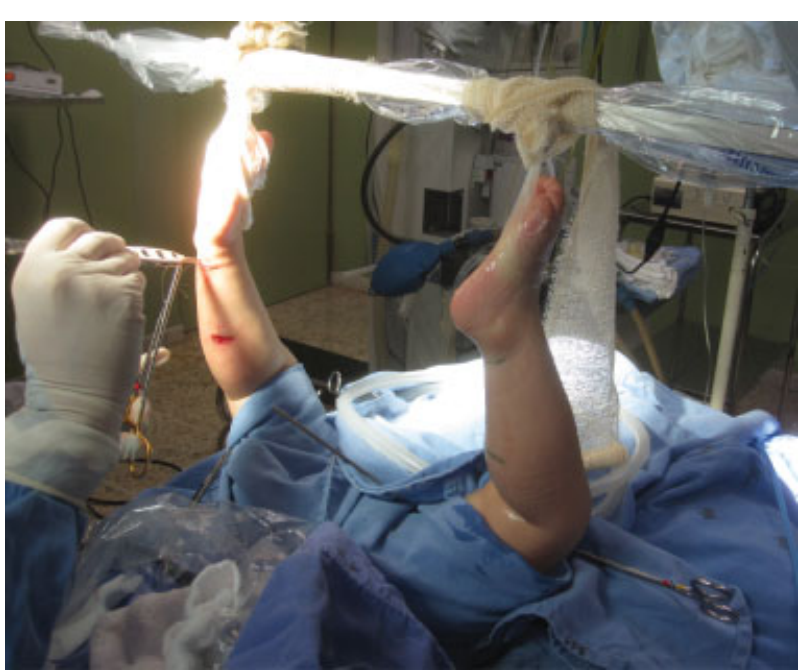

Fig. 1 Patient positioning for the endoscopic procedure. The feet are fixed on the arch with adhesive tape or bandaging.

6) Endoscopic SN microdissection, which begins with separation of the sural nerve from the small saphenous vein (-Fig. $\mathbf{3 A}$ and $\mathbf{B}$ ).

7) Release of the $\mathrm{SN}$ and incision of the gastrocnemius muscle fascia (-Fig. 3C). Exchange of the short speculum for a long speculum.

8) Incision at the back of the leg, using the tip of the endoscopic speculum as a reference, and dissection to the endoscopic working area.

9) Passing of the silicone repair tape from the nerve via the endoscopy tunnel to the incision at the back of the leg.

10) Repositioning of the nasal speculum through the new incision and reintroduction of the endoscope with microdissection in the popliteal fossa.

11) Externalization of the SN and suturing by planes. Depending on the degree of release of the SN from the fascia, one or two incisions can be made ( - Fig. 3D and E).

\section{Results}

During the period of 2012-2014, seven cases of obstetric plexopathy were selected for endoscopic SN harvesting.

In two patients, only one SN was harvested. In the other five patients, both SNs were removed, for a total of 12 endoscopically harvested SNs.

The mean harvesting time of each SN was 45 minutes. The maximum time was 65 minutes, whereas the minimum time was 35 minutes.

Nine SNs were harvested using only two incisions.

Three SNs were harvested through three incisions.

The mean incision size was $20 \mathrm{~mm}$, with a minimum size of $15 \mathrm{~mm}$ and a maximum size of $26 \mathrm{~mm}$.

Only one gauze was used during the harvesting of two SNs. In the case of one patient, only one gauze was used for each SN.

\section{Discussion}

The SN is the best graft source in NBPL reconstructions. ${ }^{1,2,6}$ The $\mathrm{SN}$ is placed between the proximal stumps (cervical root) and distal stumps (trunk divisions) after neuroma's removal (-Fig. 4). The classical sural harvesting techniques, which include a longitudinal incision from the ankle to the popliteal fossa or incisions in multiple steps (with transverse incisions), have the disadvantage of greater blood loss and large scars that may cause contractures and deformities of the equinovarus type. ${ }^{6,7}$

The endoscopic technique was developed to minimize surgical trauma, decrease the skin incision size and, therefore, decrease the likelihood of lower limb deformities. ${ }^{5-7}$

Endoscopic techniques have been widely used in the harvesting of the saphenous vein and the radial artery for vascular surgeries with the advantages of minimal scars and less postoperative complications, such as hypersensitivity of the skin, scars and infections. ${ }^{8,9}$
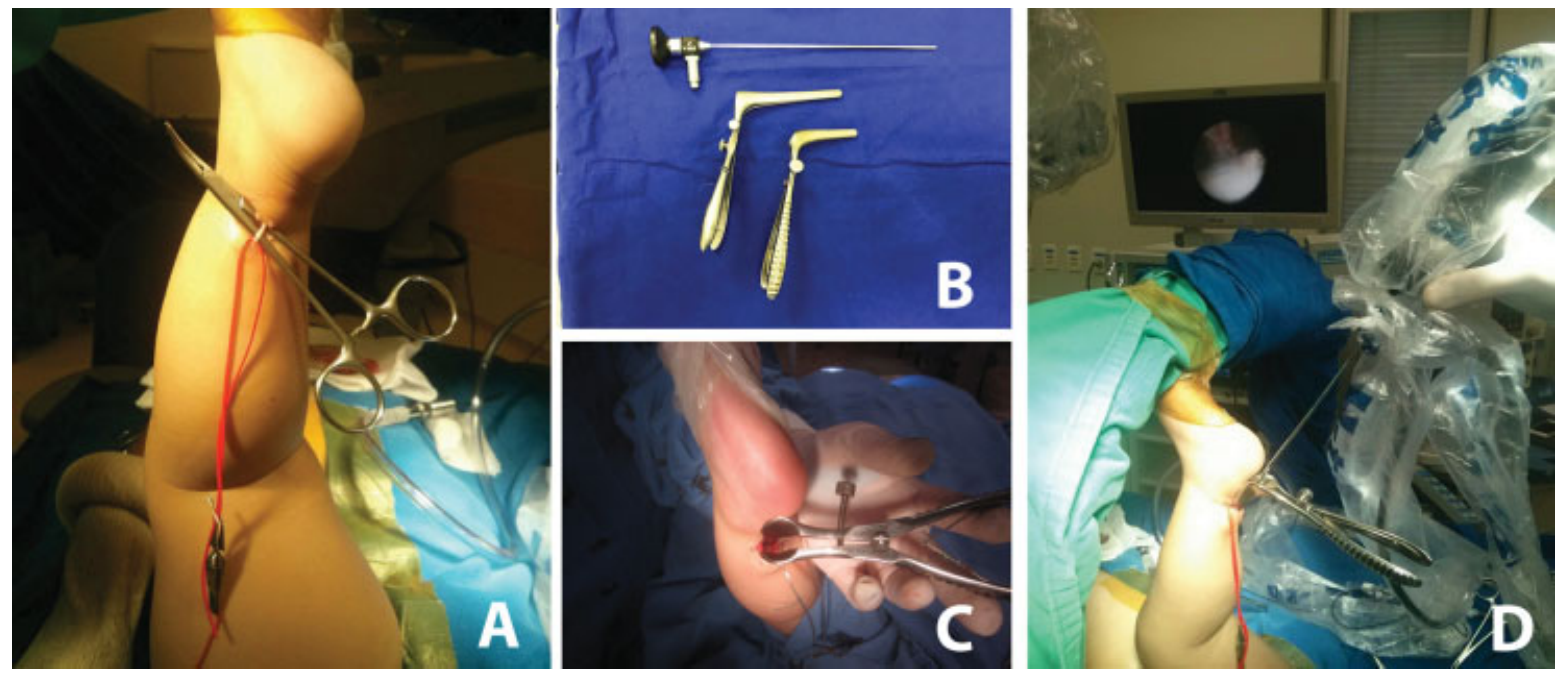

Fig. 2 Initial step of the endoscope procedure. (A) Macroscopic dissection and repair of the sural nerve with silicone tape. (B) Instruments used for the endoscopic procedure. (C) Introduction of the short speculum into the ankle incision. (D) Introduction of the endoscope through the tunnel formed by the speculum. 

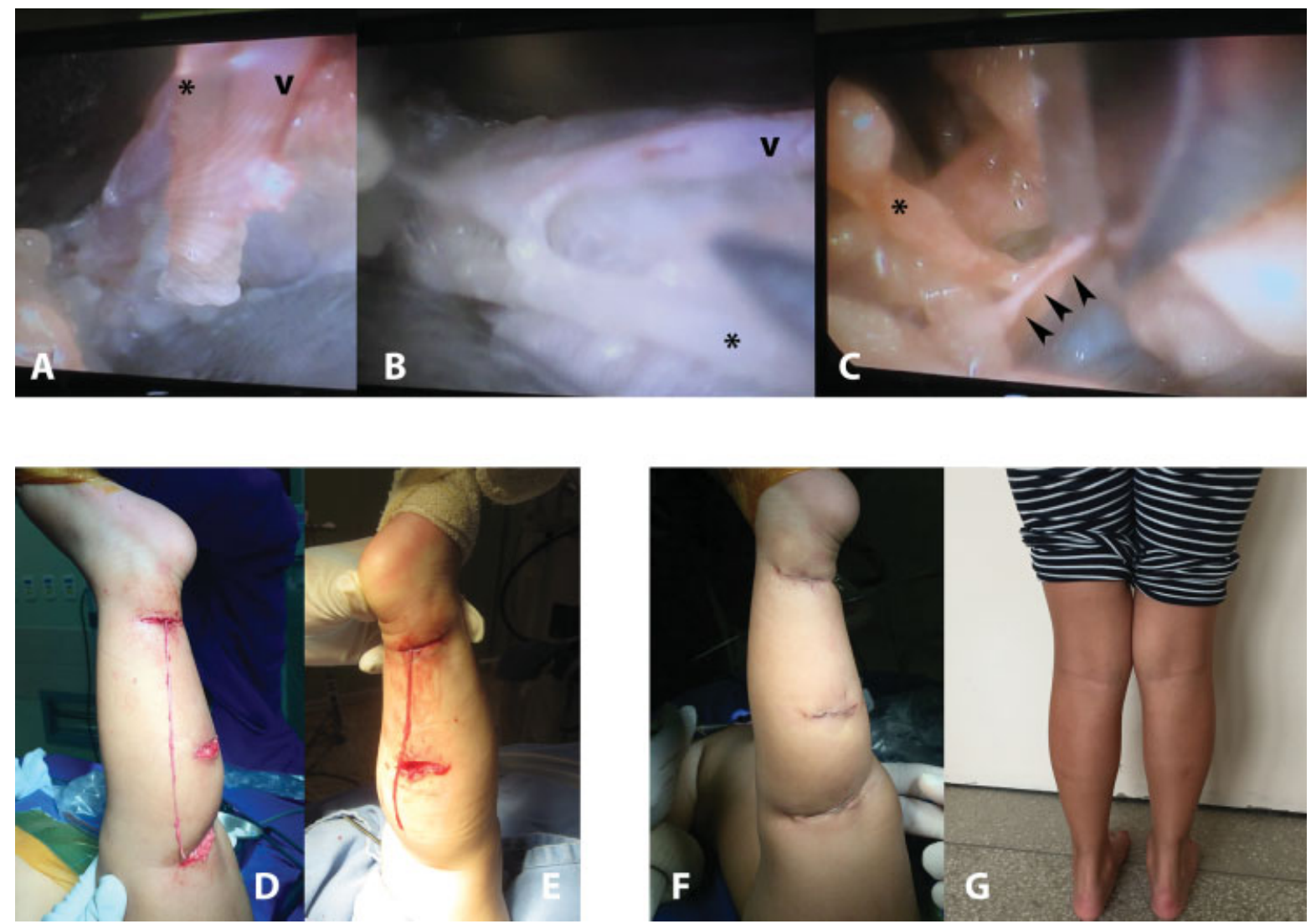

Fig. 3 Endoscopic steps for dissection of the sural nerve. (A and B) Initial dissection of the sural nerve from the small saphenous vein. (C) Incision of the gastrocnemius muscle fascia. D and $\mathrm{E}$ - Sural nerve externalization using three (D) or two incisions (E). (F) Final appearance after suture. (G) Healing four years after the procedure (asterisk = sural nerve; $v=$ small saphenous vein)

There is now the option of harvesting the SN endoscopically, with only one incision, using the same endoscopic instruments as in vascular surgery. ${ }^{5}$

This system, namely Guidant VasoView Uniport Plus (Guidant Corp., Indianapolis, IN, USA) optimizes SN harvesting, requiring only one $12-13 \mathrm{~mm}$ incision and a mean operative time of 20 minutes. ${ }^{5,6}$ The greatest drawback of this device is

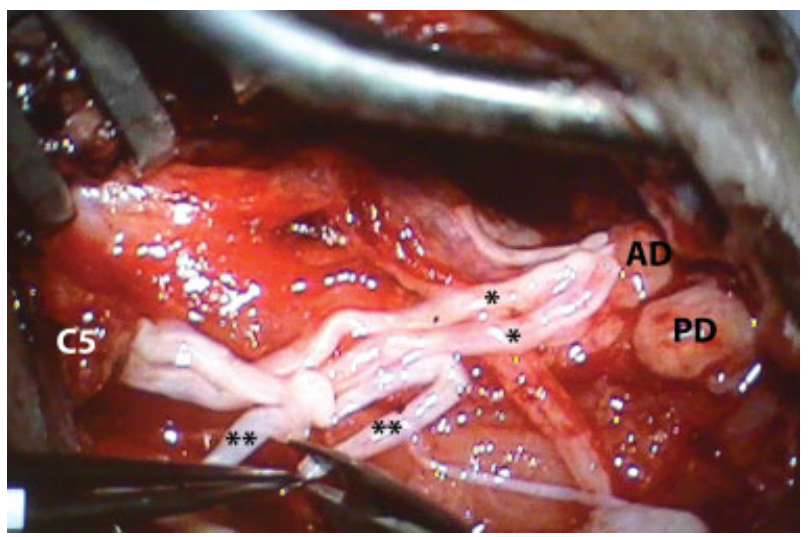

Fig. 4 Intraoperative photo of brachial plexus reconstruction using a sural nerve graft after removal of the neuroma. In this case, there was a neuroma in the upper trunk that was resected. Several sural nerve fascicles were made that were grafted ("sural nerve as a graft between the $C 5$ root and anterior division (AD); ${ }^{*}$ sural nerve being prepared for grafting between $\mathrm{C} 5$ and posterior division). the high cost of purchase and maintenance, which makes it impractical in large Brazilian hospital centers. In this context, this study contributes to the literature by describing an endoscopic technique using ordinary and low-cost instruments. To our knowledge, this was the first Brazilian article to describe an endoscopic technique of SN harvesting in infants.

The advantages of the endoscopic technique described in the literature in relation to the classical technique were also observed in this study. In infants, this has an effect that should be considered because it reduces harm to the child by decreasing the heat loss caused by larger incisions; it involves less blood loss; it offers better cosmetic results and it also involves a lower likelihood of equinovarus contractures. ${ }^{6,7}$

In the first cases, we had tried to use a zero-degree endoscope, but it was much more cumbersome than using a thirty-degree endoscope. Therefore, a thirty-degree cystoscopic lens was used for the procedure, but any short and thin endoscope can be used. Blood loss was minimal and estimated at less than $5 \mathrm{ml}$ (less than one gauze); there was no change in body temperature, and all of the patients were discharged after less than 48 hours of hospitalization. Long-term monitoring of patients showed no contractures or deformities of the lower limbs, and long-term scarring was almost unnoticeable (-Fig. 3G).

The greatest drawback of the technique described in this study and of the endoscopic technique using this particular device was the longer duration of the surgery ( 45 minutes versus 20 minutes) and the number of incisions ( 2 or 3 versus 
one incision). ${ }^{5,6}$ These differences, however, did not alter the main benefits of the endoscopic technique in regard to the amount of bleeding and final aesthetic results in the short and long term.

\section{Special Thanks}

Special thanks to the neurosurgery team from Leiden, Netherlands, where the first author of this article performed training as an observer and was able to adapt such an endoscopic technique in Brazil.

\section{Conclusion}

Sural nerve harvesting in children with NBPL is feasible and it offers the advantage of needing only two or three small incisions made with basic endoscopy instruments.

\section{References}

1 van Vliet AC, Tannemaat MR, van Duinen SG, Verhaagen J, Malessy MJ, De Winter F. Human Neuroma-in-Continuity Contains Focal
Deficits in Myelination. J Neuropathol Exp Neurol 2015;74(09): 901-911

2 Malessy MJ, Pondaag W. Obstetric brachial plexus injuries. Neurosurg Clin N Am 2009;20(01):1-14, v

3 Lapid O, Ho ES, Goia C, Clarke HM. Evaluation of the sensory deficit after sural nerve harvesting in pediatric patients. Plast Reconstr Surg 2007;119(02):670-674

4 Ramakrishnan PK, Henry BM, Vikse J, et al. Anatomical variations of the formation and course of the sural nerve: A systematic review and meta-analysis. Ann Anat 2015;202:36-44

5 Park SB, Cheshier S, Michaels D, Murovic JA, Kim DH. Endoscopic harvesting of the sural nerve graft: technical note. Neurosurgery 2006;58(1, Suppl)E180, discussion E180

6 Spinks TJ, Adelson PD. Pediatric sural nerve harvest: a fully endoscopic technique. Neurosurgery 2009;64(05, Suppl 2):360-363, discussion 363-364

7 Strauch B, Goldberg N, Herman CK. Sural nerve harvest: anatomy and technique. J Reconstr Microsurg 2005;21(02):133-136

8 Vitali RM, Reddy RC, Molinaro PJ, Sabado MF, Jacobowitz IJ. Hemodynamic effects of carbon dioxide insufflation during endoscopic vein harvesting. Ann Thorac Surg 2000;70(03):1098-1099

9 Navia JL, Brozzi N, Chiu J, et al. Endoscopic versus open radial artery harvesting for coronary artery bypass grafting. J Cardiovasc Surg (Torino) 2012;53(02):257-263 